\title{
PENGARUH DISCHARGE PLANNING DENGAN PENDEKATAN FAMILY CENTERED NURSING TERHADAP KUALITAS HIDUP PASIEN STROKE
}

\author{
Milya Novera ${ }^{1)}$ Ledia Restipa $^{2)}$ Diana Arianti $^{3}$ \\ 1) Ilmu Keperawatan STIKes Alifah Padang \\ Jl. Khatib Sulaiman No. 52 B Padang \\ email : milya_novera87@yahoo.co.id \\ 2) Ilmu Keperawatan STIKes Alifah Padang \\ Jl. Khatib Sulaiman No. 52 B Padang \\ email: ledia_restipa@yahoo.com \\ ${ }^{3)}$ Ilmu Keperawatan STIKes Alifah Padang \\ Jl. Khatib Sulaiman No. 52 B Padang \\ email : dianaarianti84@gmail.com
}

\begin{abstract}
Post-stroke ischemic patients tend to have residual symptoms that can affect physical functioning and daily activities in patients. The objective of this study was to determine the effect of Discharge Planning with family centered nursing approach to the quality of life of stroke patients at RSI. Ibnu Sina Padang. Design quasi experimental research, non-equivalent, control group pretest and posttest design. Sampling technique with consecutive sampling, which samples totaling 26 people are ischemic stroke patientsData analysis using Mann Whitney statistical test. Result of statistic test with $p$ value $=0,04$, there was difference of quality of life of patient stroke ischemic after given discharge planning with approach of family centered nursing. It is recommended for nurses to be able to provide discharge planning well to the patient's family in providing family support to post stroke patient besides that discharge planning also given to the patient to be able to increase motivation and high life spirits so that patients do not experience depression.
\end{abstract}

Keywords: quality of life, discharge planning, family centered nursing, stroke

\begin{abstract}
ABSTRAK
Pasien pasca stroke iskemik cendrung memiliki gejala sisa yang dapat mempengaruhi fungsi fisik dan aktifitas sehari-hari pada pasien. Penelitian ini bertujuan untuk mengetahui Pengaruh Discharge Planning Dengan Pendekatan Family Centered Nursing Terhadap Kualitas Hidup Pasien Stroke Di RSI. Ibnu Sina Padang Tahun 2016. Desain penelitian quasi experimental, non equivalent, control group pre test dan post test design. Pengambilan sampel consecutive sampling yang berjumlah 26 orang. Sampel yaitu pasien stroke iskemik. Uji statistik yang digunakan wilxocon signed test. Teknik pengambilan sampel dengan consecutive sampling. Analisis data menggunakan uji statistik Mann Whitney. Hasil uji satatistik dengan nilai $p=0,346$ artinya tidak terdapat perbedaan kualitas hidup pasien stroke siskemik sesudah diberikan discharge planning dengan pendekatan family centered nursing. Disarankan bagi perawat agar dapat memberikan disharge planning dengan baik pada keluarga pasien dalam memberikan dukungan keluarga terhadap pasien pasca perawatan stroke selain itu disharge planning juga diberikan pada pasien untuk dapat meningkatkan motivasi dan semangat hidup yang tinggi sehingga pasien tidak mengalami depresi
\end{abstract}

Kata Kunci: Kualitas hidup, discharge planning, family centered nursing, Stroke.

\section{PENDAHULUAN}

Kualitas hidup merupakan suatu penilai seseorang tentang kehidupanya.Hasil Penelitian Exel et al (2004) mengatakan adanya hubungan yang signifikan antara status fungsional dengan kualitas hidup pada fase akut setelah stroke, pasien dengan status fungsional yang jelek cenderung mempunyai kualitas hidup yang kurang baik. Menurut Feigin (2009), stroke merupakan penyebab kecacatan nomor 1 (satu) dan penyebab kematian nomor 3 
(tiga) setelah penyakit jantung koroner dan penyakit kanker sehingga penyakit stroke telah menjadi masalah kesehatan yang mendunia dan semakin penting. Penderita meninggal akibat stroke mencapai 50\% dalam kurun waktu tiga tahun, laju pertambahan penderita stroke berkisar antara 5 sampai 12 orang per 1.000 penduduk (O'Brien, 2011). Jadi dapat disimpulkan bahwa setiap 100 orang yang sehat, terancam berkemungkinan akan beresiko menderita stroke berkisar 1 sampai 2 orang, termasuk untuk orang Indonesia.

Menurut data Yayasan Stroke Indonesia mengatakan bahwa penderita stroke di Indonesia terus bertambah dari tahun ke tahun. Menurut data Riset Kesehatan Dasar (Riskesdas) tahun 2013 mendata kasus stroke di Indonesia dengan angka kejadian 12,1 per 1.000 penduduk sedangkan pada tahun 2007 angka kejadian pada pasien stroke 8 per 1.000 penduduk. Dari data diatas dapat diartikan terjadi peningkatan kejadian stroke di Indonesia setiap tahunya. Berdasarkan data Dinas Kesehatan Provinsi Sumatera Barat tahun 2015, penyakit stroke merupakan salah satu penyakit penyebab kematian terbanyak di masyarakat Sumatera Barat. Sejumlah perilaku seperti mengkonsumsi makanan siap saji yang mengandung kadar lemak jenuh tinggi, kebiasaan merokok, minum alkohol, kerja berlebihan, kurang olah raga dan stres, telah menjadi gaya hidup manusia terutama di perkotaan.

Kualitas hidup individu dipengaruhi oleh beberapa faktor yaitu faktor fisiologis, status gejala, status fungsional, persepsi kesehatan secara umum, karakteristik individu dan karakteristik lingkungan (Wilson \& Cleary, 1995). Menurut penelitian Carod et al (2007) yang mengatakan bahwa pasien stroke akan terjadi perubahan fisik, gangguan mental, gangguan koqnitif dan perunan interaksi sosial. Pasien stroke agar kualitas hidupnya lebih baik sangat tergantung pada penatalaksanaan, asuhan sehingga dibutuhkan peran serta tenaga kesehatan yang handal dan keluarga yang memiliki pengetahuan tentang penyakit, cara penanganan dan perawatan serta adaptasi yang disusun dalam Discharge planning (Almborg, 2010). Pemberian Discharge planning dapat meningkatkan pengetahuan pasien, efektifitas perawatan di rumah sakit, mengurangi kunjungan ulang ke rumah sakit serta dapat mengurangi biaya perawatan (Karen, 2000). Hal ini juga akan mempengaruhi mutu rumah sakit yaitu meningkatnya Length Of Stay (LOS) dan menurunnya Bed Turn Over (BTO).

Pada fase lanjutan atau perawatan lanjutan, diperlukan penanganan yang tepat karena dapat menimbulkan komplikasikomplikasi. Seringkali ketika pasien pulang dari rumah sakit, pasien pasca stroke masih mengalami gejala sisa, misalnya dengan keadaan : kehilangan motorik (hemiplegi/hemiparese) atau pasien yang pulang dengan keadaan bedrest total, kehilangan komunikasi atau kesulitan berbicara (disatria), gangguan persepsi, kerusakan fungsi kognitif dan efek psikologik, sehingga akan berdampak pada aktivitas hidup sehari-hari (Activitas of DailyLiving $=$ ADL) dalam pemenuhan kebutuhan dasar manusia. Pemberian pelayanan perawatan yang baik di rumah sakit akan mempercepat proses penyembuhan pasien stroke. Lama standar minimal perawatan pasien stroke rata-rata 2 sampai 4 minggu (Hellen, 2007). Setelah itu pasien stroke akan melakukan perawatan rawat jalan. Kondisi pasien yang diizinkan pulang secara medis sudah membaik namun dalam pemenuhan kebutuhan dan keperawatan masih sangat terbatas, sehingga diperlukan penanganan perawatan rumah paska rawat di rumah sakit.

Ketidaktahuan atau ketidakmampuan pasien dan keluarga mengenai cara 
perawatan di rumah berdampak pada masalah kesehatan atau ketidaksiapan pasien menghadapi pemulangan setelah dirawat di rumah sakit. Tinjauan literatur mengindikasikan bahwa rumah sakit seringkali melakukan Discharge planning pada pasien dengan perencanaan yang tidak mencukupi, instruksi yang buruk, informasi yang tidak cukup, kurang koordinasi diantara anggota tim layanan kesehatan, dan komunikasi yang buruk antara rumah sakit dan komunitas. Peneliti di Belanda menemukan bahwa 2 minggu setelah dipulangkan $93 \%$ pasien mengalami satu atau lebih masalah kesehatan.Masalah ini menghasilkan rawatan ulang yang tidak diperlukan, penyembuhan fungsional yang buruk dan kualitas hidup yang buruk (Potter dan Perry, 2006).

Peran keluarga sangat penting dalam tahap-tahap perawatan kesehatan, mulai dari tahapan peningkatan kesehatan, pencegahan, pengobatan, sampai dengan rehabilitasi. Dukungan sosial dan psikologis sangat diperlukan oleh setiap individu di dalam setiap siklus kehidupan, dukungan sosial akan semakin dibutuhkan pada saat seseorang sedang menghadapi masalah atau sakit, disinilah peran anggota keluarga diperlukan untuk menjalani masa-masa sulit dengan cepat.12 Salah satu dukungan keluarga yang dapat di berikan yakni dengan melalui perhatian secara emosi, diekspresikan melalui kasih sayang dan motivasi anggota keluarga yang sakit agar terus berusaha mencapai kesembuhan, Dalam penerapan proses keperawatan di rumah terjadi proses alih peran dari perawat kepada klien dan keluarga (sasaran) secara bertahap dan berkelanjutan untuk mencapai kemandirian klien dan keluarga sasaran dalam menyelesaikan masalah kesehatannya (Depkes, 2006). Peningkatan kualitas hidup adalah tujuan utama yang diharapkan dalam perawatan pasien stroke iskemik paska rawat inap.
Berdasarkan wawancara dengan 7 orang pasien stroke dan keluarganya paska rawat inap RSI. Ibnu Sina Padang, 4 orang pasien mengatakan ketidaktahuan pasien dan keluarga akan perawatan pasien selama di rumah, 3 orang pasien menyatakan bahwa pasien dan keluarganya kurang mendapatkan informasi mengenai rencana perawatan yang dilakukan, ini merupakan bukti gagalnya informasi yang disampaikan petugas kesehatan saat discharge planning. Selain itu keluarga juga menyatakan bahwa belum ada motivasi dan dukungan dari keluarga untuk merawat anggota keluarga stroke dikarenakan kurangnya pengetahuan dan keterampilan tentang cara merawat anggota keluarga pasca stroke sehingga tidak terpenuhi kebutuhan dasar pasien antara lain kurangnya perawatan diri, kurangnya intake cairan dan nutrisi, tidak dilakukan mobilisasi dan muncul beberapa komplikasi dan belum ada perawat melatih dan mengajarkan pada keluarga tentang cara merawat pasien pasca stroke, sehingga keluarga belum bisa secara mandiri melakukan perawatan kesehatan pada anggota keluarga dengan pasca stroke. Berdasarkan fenomena atau kondisi tersebut, peneliti sangat tertarik untuk melakukan penelitian tentang Pengaruh Discharge Planning Dengan Pendekatan Family Centered Nursing terhadap Kualitas Hidup Pasien Stroke Di RSI. Ibnu Sina Padang Tahun 2017.

\section{METODE PENELITIAN}

Penelitian ini merupakan jenis penelitian kuantitatif dengan menggunakan desain Quasy Experimental, Control Group Pre Test-Post Test Design. Pada rancangan penelitian ini, subjek dibagi dalam dua kelompok yaitu kelompok yang mendapat perlakuan penelitian (intervensi) dan kelompok yang sesuai dengan kebiasaan saat ini (kontrol) yang semuanya akan 
dilakukan pengukuran sebelum dan setelah dilakukan perlakuan. Populasi semua pasien stroke rawat inap di Ruang syaraf RSI.Ibnu Sina Padang pengambilan sampel menggunakan consecutive sampling) sebanyak 26 orang pasien paska stroke yang dibagi menjadi 13 orang untuk kelompok kontrol yang mendapat tindakan biasa dan 13 orang kelompok intervensi. Penelitian ini dilakukan di rumah sakit RSI.Ibnu Sina Padang. Penelitian ini dimulai pada bulanApril- Agustus 2017.

\section{HASIL DAN PEMBAHASAN}

Penelitian ini telah dilakukan \pm 6 di Rumah Ibnu Sina Padang dengan jumlah responden sebanyak 26 orang pasien stroke. Penyajian hasil penelitian ini meliputi data karakteristik responden, data kesiapan dan analisis uji statistik.

1. Mengidentifikasi Kualitas Hidup Pasien Stroke Iskemik sebelum dan Sesudah pada kelompok Kontrol diberikan Discharge Planning dengan Pendekatan Family Centered Nursing di RSI. Ibnu Sina Padang

\begin{tabular}{lccccc}
\hline \multirow{2}{*}{ Variabel } & \multicolumn{3}{c}{ Sebelum } & \multicolumn{2}{c}{ Sesudah } \\
\cline { 2 - 6 } & Mean & SD & Mean & SD & P \\
& & & & & Value \\
\hline Fungsi Fisik (FF) & 21,53 & 3,10 & 21,53 & 5,75 & 0.817 \\
Peranan Fisik (PF) & 5,38 & 1,48 & 5,38 & 1,39 & 0.852 \\
Rasa Nyeri (RN) & 3,84 & 1,03 & 3,84 & 1,11 & 0.831 \\
Kesehatan Umum & 3,38 & 1.18 & 6,15 & 1,40 & 0.959 \\
(KU) & 19,00 & 0.86 & 6,38 & 1,05 & 1.000 \\
Fungsi Sosial (FS) & 6,33 & 1.56 & 13,92 & 2,70 & 0.938 \\
Vitalitas (V) & 14.00 & 2.00 & 18,92 & 3,37 & 0.928 \\
Kesehatan Mental & 6.25 & 2,97 & 16,30 & 2,66 & 0.781 \\
(KM) & 3,41 & 1,15 & 3,46 & 1,33 & 1.000 \\
Peranan Emosi (PE) & & & & & \\
Ringkasan Fisik \& & & & & & \\
Mental & 95.92 & 10.8 & 95,92 & 10,84 & 0.837 \\
(RFM) & & 5 & & & \\
Kualitas Hidup & & & & & \\
\hline
\end{tabular}

Berdasarkan tabel 5.3 dapat diketahui bahwa kualitas hidup sebelum dan sesudah pada kelompok kontrol diberikan discharge planning dengan pendekatan family centered nursing memperoleh nilai 0.837 yang artinya tidak terdapat perbedaan kualitas hidup pasien iskemik responden sebelum dan sesudah diberikan discharge planning dengan pendekatan family centered nursing. Berdasarkan hasil uji statistik dengan Mann Whitney didapatkan nilai $\mathrm{p}=0,0.837$ dimana nilai $\mathrm{p}>0.05$.

Hasil interpretasi data yang dilakukan pada kelompok kontrol diketahui bahwa kualitas hidup kelompok kontrol sebelum diberikan discharge planning dengan pendekatan family centered nursing memperoleh nilai rata-rata 95.92 dengan standar deviasi 10.84. Sedangkan kualitas hidup kelompok kontrol sesudah diberikan discharge planning dengan pendekatan family centered nursing memperoleh nilai rata-rata 95,92. Hal ini menunjukkan bahwa kualitas hidup responden untuk merawat pasien stroke sesudah diberikan discharge planning dengan pendekatan family centered nursing meningkat menjadi lebih baik dibandingkan sebelum diberikan. Kesiapan kelompok kontrol sebelum diberikan Discharge Planning menunjukkan bahwa kesiapan responden sesudah diberikan perencanaan pulang sesuai standar rumah sakit lebih baik dibandingkan sebelum diberikan.

Serangan stroke banyak gejala yang timbul seperti lumpuh separuh badan, mulut mencong, bicara pelo, sulit menelan, sulit berbahasa (kurang dapat mengungkapkan apa yang ia inginkan), tidak dapat membaca dan menulis, kepandaian mundur, mudah lupa, penglihatan terganggu, pendengaran mundur, perasaan penderita akan lebih sensitif, gangguan seksual, bahkan sampai mengompol, dan tidak dapat buang air besar sendiri (Hartanti, 2002) dalam 
(Anggarani 2009). Orang dewasa yang mengalami penyakit stroke akan mengalami kecacatan akibat stroke dapat berupa pembatasan fisik, disfungsi sosial, psikologi yang dapat menyebabkan perubahan kondisi sehingga mempengaruhi banyak aspek kualitas kesehatan berhubungan dengan kehidupan atau kualitas hidup (Rahmi, 2011). Berkurangnya tingkat kemandirian dan mobilitas seseorang dapat berpengaruh terhadap kualitas hidup (quality of life) yang dimiliki.

Kualitas hidup merupakan sehat fisik, mental dan sosial dan terlepas dari penyakit (Fayers \& Machin, 2000). Terbukti pada saat peneltian ditemukan bahwa pada saat ditanyakan tentang aktivitas yang biasa dilakukan sehari-hari menjadi terbatas atau terganggu karena kondisi kesehatan yaitu pada saat menekuk tubuh, berlutut, membungkuk. Paralisis ekstremitas yang akan menghambat pasien untuk mobilisasi sehingga membutuhkan mendapatkan perhatian khusus, perawatan diri sehingga akan mengalami gangguan dalam aktivitas hidup sehari-hari, pembatasan dalam aktivitas untuk mengisi waktu luang akibat adanya kegagalan fisik atau gangguan kognitif, tetapi dapat juga disebabkan oleh faktor psikologis, atau bahkan karena ketakutan bahwa aktivitas akan memicu stroke ulang.

2. Mengidentifikasi Kualitas Hidup Pasien Stroke Iskemik sebelum dan Sesudah pada kelompok intervensi diberikan Discharge Planning dengan Pendekatan Family Centered Nursing di RSI. Ibnu Sina Padang

Kualitas Hidup Pasien Stroke Sebelum dan Sesudah pada kelompok intervensi diberikan Discharge Planning dengan Pendekatan Family Centered Nursing di RSI. Ibnu Sina Padang. Hasil analisis data dilihat pada Tabel 4 berikut:

\begin{tabular}{lccccc}
\hline \multicolumn{1}{c}{ Variabel } & \multicolumn{3}{c}{ Sebelum } & \multicolumn{2}{c}{ Sesudah } \\
\cline { 2 - 6 } & Mean & SD & Mean & SD & $\begin{array}{c}\text { P } \\
\text { Value }\end{array}$ \\
\cline { 2 - 6 } & & & & & \\
Fungsi Fisik (FF) & 22,00 & 5,75 & 24,86 & 5,75 & 0.004 \\
Peranan Fisik (PF) & 5,46 & 1,39 & 6,23 & 1,39 & 0.015 \\
Rasa Nyeri (RN) & 3,92 & 1,11 & 4,07 & 1,11 & 0.018 \\
Kesehatan Umum & 6,15 & 1,40 & 6,07 & 1.40 & 0.026 \\
(KU) & 6,46 & 1,05 & 6,07 & 1.05 & 0.023 \\
Fungsi Sosial (FS) & 14,00 & 2,70 & 15,46 & 2.70 & 0.016 \\
Vitalitas (V) & 18,95 & 3,37 & 19.23 & 3.37 & 0.015 \\
Kesehatan Mental & 16,23 & 2,66 & 15.76 & 2,68 & 0.012 \\
(KM) & 3,46 & 1,33 & 3,00 & 1,33 & 0.021 \\
Peranan Emosi (PE) & & & & & \\
Ringkasan Fisik \& & & & & & \\
Mental & 96,61 & 11,63 & 100.7 & 6.37 & 0.04 \\
(RFM) & & & 6 & & \\
Kualitas Hidup & & & & & \\
\hline
\end{tabular}

Berdasarkan data di atas dapat diketahui bahwa kualitas hidup sebelum dan sesudah pada kelompok intervensi diberikan discharge planning dengan pendekatan family centered nursing memperoleh nilai 0.04 yang artinya terdapat perbedaan kualitas hidup pasien iskemik responden sebelum dan sesudah diberikan discharge planning dengan pendekatan family centered nursing. Berdasarkan hasil uji statistik dengan Mann Whitney didapatkan nilai $\mathrm{p}=0,04$ dimana nilai $\mathrm{p}>$ 0.05 .

Hasil interpretasi data yang dilakukan pada kelompok intervensi diketahui bahwa kualitas hidup kelompok intervensi sebelum diberikan discharge planning dengan pendekatan family centered nursing memperoleh nilai rata-rata 96.61 dengan standar deviasi 11,63, sedangkan intervensi diketahui bahwa kualitas hidup kelompok perlakuan sebelum diberikan discharge planning dengan pendekatan family centered nursing memperoleh nilai rata-rata 100.76 dengan standar deviasi 6.37.

Kualitas hidup sebelum dan sesudah pada kelompok intervensi diberikan discharge planning dengan pendekatan family centered nursing memperoleh nilai 0.04 yang artinya terdapat perbedaan 
kualitas hidup pasien iskemik responden sebelum dan sesudah diberikan discharge planning dengan pendekatan family centered nursing. Berdasarkan hasil uji statistik dengan Mann Whitney didapatkan nilai $\mathrm{p}=0,04$ dimana nilai $\mathrm{p}>0.05$.

Hal ini menunjukkan bahwa kualitas hidup responden untuk merawat pasien stroke sesudah diberikan discharge planning dengan pendekatan family centered nursing meningkat menjadi lebih baik dibandingkan sebelum diberikan. Discharge planning merupakan suatu proses yang dinamis dan sistematis dari penilaian, persiapan, serta koordinasi yang dilakukan untuk memberikan kemudahan pengawasan pelayanan kesehatan dan pelayanan sosial sebelum dan sesudah pulang (Nursalam, 2014).

\section{Menurut Nursalam} mengungkapkan tujuan discharge planning adalah menyiapkan pasien dan keluarga secara fisik, psikologis, dan sosial, meningkatkan kemandirian pasien dan keluarga, meningkatkan keperawatan yang berkelanjutan pada pasien.

3. Mengidentifikasi Kualitas Hidup Pasien Stroke Iskemik Sesudah pada kelompok kontrol dan intervensi diberikan Discharge Planning dengan Pendekatan Family Centered Nursing di RSI. Ibnu Sina Padang

\begin{tabular}{|c|c|c|c|c|c|}
\hline \multirow[t]{2}{*}{ Variabel } & \multicolumn{2}{|c|}{$\begin{array}{c}\text { Sesudah } \\
\text { Intervensi }\end{array}$} & \multicolumn{2}{|c|}{$\begin{array}{l}\text { Sesudah } \\
\text { kontrol }\end{array}$} & \\
\hline & $\begin{array}{c}\text { Mea } \\
\mathbf{n}\end{array}$ & SD & Mean & SD & $\begin{array}{c}\mathbf{P} \\
\text { Valu }\end{array}$ \\
\hline
\end{tabular}

Berdasarkan tabel di atas dapat diketahui bahwa kualitas hidup kelompok intervensi sesudah diberikan discharge planning dengan pendekatan family centered nursingmemperoleh nilai 0.342 yang artinya tidak terdapat perbedaan kualitas hidup pasien iskemik responden sesudah diberikan discharge planning dengan pendekatan family centered nursing.
Berdasarkan hasil uji statistik dengan Mann Whitney didapatkan nilai $\mathrm{p}=0,342$ dimana nilai $\mathrm{p}>0.05$.

Kualitas hidup pasien stroke iskemik sesudah pada kelompok kontrol dan intervensi diberikan discharge planning dengan pendekatan family centered nursing memperoleh nilai 0.342 yang artinya tidak terdapat perbedaan kualitas hidup pasien siskemik responden sesudah diberikan discharge planning dengan pendekatan family centered nursing. Berdasarkan hasil uji statistik dengan Mann Whitney didapatkan nilai $\mathrm{p}=0,346$, dimana nilai $\mathrm{p}$ $>0.05$.

Pemberian discharge planning sesuai prosedur rumah sakit dilakukan hanya pada saat pasien akan pulang yang berupa petunjuk pasien pulang. Pemberian discharge planning pada keluarga dan pasien meliputi informasi yang berkisar tentang waktu kontrol, cara minum obat, pemberian surat rujukan, surat sakit, dan perubahan gaya hidup yang harus dilakukan. Informasi ini belum dikemas dalam format pendidikan kesehatan yang sesuai dengan kondisi pasien. Keluarga tidak diberikan promosi kesehatan yang memadai tentang penyakit stroke dan cara perawatan lanjutan saat di rumah nanti. Discharge planning yang efektif seharusnya dimulai pada saat pasien mendapatkan pelayanan kesehatan yang diikuti dengan kesinambungan perawatan baik dalam proses penyembuhan maupun dalam mempertahankan derajat kesehatannya sampai pasien merasa siap untuk kembali ke lingkungannya

Peningkatan secara signifikan motivasi dan kesiapan keluarga dalam merawat pasien stroke pasca akut setelah diberikan discharge planning dengan pendekatan family centered nursing diperkuat dengan hasil perhitungan odd ratio yang menunjukkan bahwa pemberian discharge planning dengan pendekatan 
family centered nursing mempunyai peluang 7,2 kali lebih besar untuk meningkatkan motivasi keluarga dibandingkan dengan diberi discharge planning sesuai prosedur rumah sakit. Sedangkan pemberian pemberian discharge planning dengan pendekatan family centered nursing mempunyai peluang 4,8 kali lebih besar untuk meningkatkan kesiapan keluarga dibandingkan dengan diberi discharge planning sesuai prosedur rumah sakit.

\section{UCAPAN TERIMAKASIH}

Penelitian ini tidak lupuh dari segala bantuan dan arahan dari berbagai pihak, terutama peneliti mengucapkan terima kasih kepada:

1. Ketua Sekolah Ilmu Kesehatan Alifah Padang dan bagian UPPM yang telah memberi kesempatan untuk peneliti dalam melakukan penelitian.

2. Direktur RSI Ibnu Sina Padang bersedia membantu dan menfasilitisi peneliti dalam penelitian ini.

\section{SIMPULAN}

1. Karakteristik Pasien Stroke iskemik di RSI Ibnu Sina Padang pada pada kelompok kontrol $84.0 \%$ berjenis kelamin perempuan, tingkat pendidikan $66,7 \%$ SMU, rata-rata umur $\geq 60$ tahun, sedangkan pada kelompok intervensi $53.8 \%$ berjenis kelamin perempuan, tingkat pendidikan $53.4 \%$ berpendidikan SMA serta umur $\geq 60$ tahun.

2. Karakteristik keluarga yang merawat Pasien Stroke iskemik di RSI Ibu Sina Padang kelompok kontrol 84.6\% berjenis kelamin perempuan, tingkat pendidikan $46.2 \%$ SMA dan tingkat pendidikan SMP sebesar 38.5\% , ratarata umur $<45-5$ tahun $69,2 \%$, sedangkan pada kelompok intervensi
$84.6 \%$ berjenis kelamin perempuan, tingkat pendidikan $\quad 47.2 \%$ berpendidikan SMA serta umur $<45-55$ tahun yaitu $46.2 \%$.

3. Tidak ada perbedaan kualitas hidup sebelum dan sesudah pada Kelompok kontrol pasien stroke iskemik di RSUP Dr. M. Djamil Padang Tahun 2017.

4. Ada perbedaan kualitas hidup sebelum dan sesudah pada Kelompok intervensi pasien stroke iskemik di RSUP Dr. M. Djamil Padang Tahun 2017.

5. Tidak ada perbedaan kualitas hidup sesudah pada kelompok kontrol dan sesudah pada kelompok intervensi pasien stroke iskemik di RSUP Dr. M. Djamil Padang Tahun 2017

\section{DAFTAR PUSTAKA}

Almborg, HA.2010. Discharge After Stroke-Importan Factor For Health. Realeted Quality of Life. Journal of Clinical Nursing. 19. 2196.

Balitbang Kemenkes RI. 2013. Riset Kesehatan Dasar; RISKESDAS.Jakarta: Balitbang Kemenkes RI.

Carod AJF \& Egido Aj. 2009.Quality \& Life After Strolie: The Importance Of a good recovery. Depertemen of Nevrology Sarah Hospital, the Sarah Network of rehabilitation Hospitals, Brasilia, Brazil ; Stroke unit, Departement of Neorology, San Carlos Hospital, Madrid, Spain.

Cawthorn, L. 2005. Discharge Plenning Under the umbrella of Advanced Nursing Practice case manager. Canada : Longwoods Publishing

Depkes RI, 2006. Pedoman Kegiatan Perawat Kesehatan Masyarakat diPuskesmas. Direktorat Bina Pelayanan Keperawatan Direktorat Bina Pelayanan Medik. Jakarta.

DinKes Prov. SumBar .2015. Profil Kesehatan Sumatera BaratTahun 2016 
Discharge Planning Association .2008.Discharge Planning di http : www discharge planning. Org. Au/ index.Htm. Diunduh pada tanggal 28 April 2016.

Exel van NJA, Scholte of Reimer WJM, Koopman Schap MA. 2004. Assesmrnt of post - stroke Quality of life Costeffectivennes studies : the usefulness of Barthel Index and euro Qol - SD. Qual life Res 13 : 427 - 33

Feigin et al..2009.Worldwide Stroke Incidence And Early Case Fatality Reported In 56 Population-Based Studies: A Systematic Review. 2(8), 1409-1416.

Feigin, V. Stroke. Jakarta: PT Bhuana Ilmu Populer. 2009

Friedman, Bowden and Jones., 2003. Family Nursing: Research, Theory and Practice. Fifth edition, Prentice Hall.

Friedman, M.M, Bowden, V.R, \& Jones, E.G. 2010.Buku Ajar Keperawatan Keluarga: Riset, Teori, dan Praktik, Alih Bahasa Akhiri Yani S. Hamid dkk. Ed 5. Jakarta: EGC.

Harsono, E.D. 2000. Kapita Selekta Neurologi. Yogjakarta: Gadjah Mada university Press.

Hellen W. (2007).Altered Living : copis, hope and Quality of life after stroke. British Journal of Nursing.Vol. 16 - No 20.

Karen A, Grimer, Jhon RM, \& Tiffani KG. 2000. Discharge Plannts Quality From the carer perspective. Quality of research.g : 1005-1013.

Kozier, B. 2004.Fundamental Of Nursing Concept Process and Practice. 1stVolume 6 th Edition. New Jersey. Pearson/Prentice Hall.

O'Brien EC, Rose KM, Patel MD, Murphy CV, Rosamond WD. . 2011.Clinical Outcomes among Stroke Patients Receiving Tissue Plasminogen Activator Therapy Beyond the 3-hour Time Window. Journal of stroke and cerebrovascular diseases : the official journal of National Stroke AssociationJan 12.

Perry AG \& Potter PA.2006.Clinical Nursing Skill \& Technique. $6^{\text {th }}$ edition.Missouri: Mosby Inc.

Price S \& Wilson L. Patofisiologis.Konsep Klinis Proses proses Penyakit. Edisi 6. Jakarta: EGC. 2006

Rahmi U. Pengaruh Discharge Planning Terstruktur Terhadap Kualitas Hidup Pasien Stroke Iskemik Di RSUD AlIhsan Bandung tahun 2011 [Tesis]. Depok: Fakultas Ilmu Keperawatan UI; 2011

WHO. (2004). Introducing the WHO QOL Instruments. Diakses dari http : // dept. Washington . Edi / ygol / docs / whogol.Info Pdf pada tanggal 01 April 2016. 